Texas A\&M University- San Antonio

Digital Commons@ Texas A\&M University-San Antonio

History Faculty Publications

College of Arts and Sciences

2005

\title{
Publishing Archaeology in Science and Scientific American, 1940-2003
}

\author{
R. L. Lyman
}

Michael J. O'Brien

Texas AઐM University-San Antonio, Mike.Obrien@tamusa.edu

M. B. Schiffer

Follow this and additional works at: https://digitalcommons.tamusa.edu/hist_faculty

Part of the Anthropology Commons

\section{Repository Citation}

Lyman, R. L.; O'Brien, Michael J.; and Schiffer, M. B., "Publishing Archaeology in Science and Scientific American, 1940-2003"

(2005). History Faculty Publications. 19.

https://digitalcommons.tamusa.edu/hist_faculty/19

This Article is brought to you for free and open access by the College of Arts and Sciences at Digital Commons @ Texas A\&M University- San Antonio. It has been accepted for inclusion in History Faculty Publications by an authorized administrator of Digital Commons @ Texas A\&M University- San Antonio. For more information, please contact deirdre.mcdonald@tamusa.edu. 


\title{
PUBLISHING ARCHAEOLOGY IN SCIENCE AND SCIENTIFIC AMERICAN, 1940-2003
}

\author{
R. Lee Lyman, Michael J. O’Brien, and Michael Brian Schiffer
}

\begin{abstract}
Many new, or processual, archaeologists of the 1960s argued that Americanist archaeology became scientific only in the 1960s. The hypothesis that the rate of publication of archaeological research in Science and Scientific American increased after about 1965, as new archaeologists sought to demonstrate to their peers and other scientists that archaeology was indeed a science, is disconfirmed. The rate of archaeological publication in these journals increased after 1955 because the effort to be more scientific attributed to the processualists began earlier. Higher publication rates in both journals appear to have been influenced by an increased amount of archaeological research, a higher rate of archaeological publication generally, and increased funding. The hypothesis that editorial choice has strongly influenced what has been published in Science is confirmed; articles focusing on multidisciplinary topics rather than on narrow archaeological ones dominate the list of titles over the period from 1940 through 2003.
\end{abstract}

Muchos de los arqueólogos nuevos o 'procesales' de los años sesenta argumentaron que la arqueología Americanista solamente llegó a ser científica en los años sesenta. I a hipótesis de que el índice de publicaciones en investigación arqueológica de las revistas Science y Scientific American aumentó después de 1965, año en el que muchos arqueólogos intentaron mostrar a sus colegas y a otros científicos que la arqueología era efectivamente una ciencia, se desaprueba. El indice de publicaciones en estas revistas científicas aumentó después de 1955 porque este esfuerzo de los 'procesalistas' de llegar a ser mas científicos ya habia empezado antes. Los altos indices de publicación en ambas revistas parecen haber sido afectados por una gran cantidad de investigación arqueológica, por un alto índice de publicaciones arqueológicas en general, y por un crecido financiamiento. La hipótesis de que la selección editorial ha influenciado fuertemente los artículos publicados en Science se confirma; artículos que se concentran mas en temas multidisciplinarios que en temas arqueológicos limitados son los que dominan la lista de artículos escritos entre 1940 y 2003.

$\mathrm{T}$ hroughout the twentieth century, archaeologists in North America contended that their discipline is a science (Caldwell 1959; Kidder 1932; Meggers 1955; Plog 1982). This claim became especially strident in the 1960s and early 1970s (Binford 1972; Fritz and Plog 1970; Watson et al. 1971). We agree with many who over the past 100 years or so have argued that archaeology can be and often is scientific (O'Brien et al. 2005). Indeed, results of archaeological research have appeared in national scientific journals such as Science and Scientific American, two journals that since their inceptions have published many papers on diverse scientific topics. Articles on various aspects of human prehistory appeared in issues of both journals during the late nineteenth century and throughout the twentieth century. This observation, however, reveals little about the history of the discipline, something in which we are quite interested. It is well known that during the 1960s there was a shift in the conceptions held by some archaeologists as to how archaeological practice could become scientific (Binford 1968a, 1968b; Fritz and Plog 1970; Watson et al. 1971). Here we examine one variable that might indicate whether archaeological research was more, or less, "scientific" at different times. Although we find that this variable - the rate of archaeological publication in scientific journals - is not a very good indicator of the scientific emphasis in archaeology, it leads us

R. Lee Lyman and Michael J. O'Brien a Department of Anthropology, University of Missouri, 107 Swallow Hall, Columbia, MO 65211, USA.

Michael Brian Schiffer $\bullet$ Department of Anthropology, University of Arizona, Tucson, AZ, 85721, USA, and Research Associate, Lemelson Center, National Museum of American History, Smithsonian Institution, Washington, D.C., USA. 
into other interesting arenas of our discipline's history.

Beginning in the 1960s and continuing into the early 1970s, some members of a segment of American archaeologists, referred to variously as "new," or "processual," archacologists (Binford 1968a, 1968b; Chang 1967; Flannery 1967; Kushner 1970), in effect claimed that only archaeology accomplished under the aegis of the new program would be scientific. "Birth" announcements of the new archaeology appeared in both Science (Hammond 1970) and Scientific American (Flannery 1967), and seminal case studies were also published in both journals (e.g., Binford and Binford 1969; Flannery 1965; Hole 1966; Leone 1968; Longacre 1964; Wilmsen 1968). These facts hinted that a closer examination might reveal previously undetected details about the history of the discipline. In particular, we wondered if publishing in such prominent science journals might serve as an indication - to archaeologists and nonarchaeologists alike- that the discipline was in fact scientific.

We recognized that the publication rate of archaeology would be influenced by variables such as rate of submission and, perhaps most importantly, editorial choice. Direct data on submission rates are unavailable, but it is not unreasonable to assume a correlation between editorial choice and the sample of manuscripts from which an editor has to choose. Frank Hole, editor of American Antiquity from 1974 to 1978 , summed up the kind of influence that a journal editor has: "Although there are a number of ways in which an editor can influence the journal, he is limited by the kinds of articles which he receives. . . [T] he bulk of material which crosses his desk arrives unannounced beforehand, and it reflects the varied interests of archaeologists who read and use the journal" (Hole 1974:405). Therefore, we used published articles as a reflection of disciplinary goals. We came to appreciate, however, that one cannot easily isolate disciplinary aspirations after the filter of editorial choice has been applied to submissions.

\section{Methods, Materials, Hypotheses}

We chose two prominent and well-known scientific journals-Science and Scientific Americanto guard against the possibility that the idiosyncrasies of a single data source would unduly influence our analysis. This decision invites others to compare our results with analyses based on publication patterns in other science journals (e.g., American Scientist, Nature). For guidance on analytical methods we examined journals specializing in the history of science. Pcrusal of Isis (described on its cover as "an international review devoted to the history of science and its cultural influences"), History of Science, and Journal of the History of the Behavioral Sciences failed to provide examples of the kind of analysis we envisioned. Thus, our data and methods are of our own design. Our data base includes the author(s), year of publication, title, volume number, issue number, and page numbers for each archaeological article. (For a copy of the data base, contact the senior author at lymanr@missouri.edu.)

We examined all issues of both journals published between 1940 and 2003 inclusively. The period is long enough to reveal temporal trends, and it spans the critical event- - emergence of the "new" scientific archaeology —of interest here. We originally had no intention of monitoring potential influences of World War II, which would have required data from the 1930s. Significant changes in formatting and structure of both journals occurred in the 1940s and early 1950s, and we wished to control for these influences. We also sought to include the development of radiocarbon dating (Arnold and Libby 1949; Libby et al. 1949) in our data, so we chose 1940 as a starting date.

Given the publication dates of the new archaeology's birth announcements (e.g., Binford 1962; Flannery 1967), early case studies (e.g., Deetz 1965; Flannery 1965; Hole 1966; Longacre 1964), and seminal volumes (e.g., Binford and Binford 1968; Clarke 1968), as well as Sterud's (1978) finding that a marked increase in the frequency of citation of processual publications began in 1968, we chose 1965 as the approximate date for when changes in publication trends should appear. Thus, if the processualist claim is correct-that archaeological research became scientific only after about 1965-then perhaps the rate at which results of archaeological research were published in Science and Scientific American would show a dramatic increase after 1965, perhaps as late as 1970 .

Scientific American has been in existence for more than 150 years. The journal's editorial policy is to publish articles about cutting-edge research in 
a manner that scientists in any discipline (and lay people) can understand. Photographs have been prominent for more than a century, and they, together with charts, maps, and line drawings of artifacts and excavations, have set an impressive standard for archaeological illustration. Authors either submit a proposal for an article, which is reviewed and accepted or rejected, or contributions are solicited and reviewed by the editors. In the past several years, authorship of articles on archaeological topics in Scientific American has, for unclear reasons, begun to shift from professional archae ologists to science journalists (e.g., Nemecek 2000). Our hypothesis concerning Scientific American was that the per-year rate of publication of archaeological papers measured as the percentage of all articles published would increase beginning about 1965.

Science has been published weekly since 1880 . In 1952, then-chairman of the editorial board, Howard Meyerhoff, reported that the journal was meant to serve as "a medium for brief but adequately documented reports of new discoveries and developments in every field of science" and as "an outlet for quick publication of significant research before definitive articles can be prepared for, and published in, the specialty journals" (Meyerhoff 1952:3a). At that time some articles, apparently a minority, were solicited by the editors, but most were submitted without solicitation. The acceptance rate was less than 50 percent. Manuscripts submitted today are typically subjected to a rigorous review process that results in a very low acceptance rate. The purported goal of Science is to reach a broad cross section of the scientific community representing multiple disciplines and (we suspect, hopefully) a sizable portion of the lay public, and most importantly, to publish new, cutting-edge results.

Similar to that for Scientific American, one hypothesis for Science is that the rate of publication of archaeological titles measured as the annual proportion of all published papers would increase beginning about 1965 . We also propose a "content hypothesis" for Science based on our subjective impressions of the journal's contents. The hypothesis is that a majority of titles concern the most newsworthy archaeological phenomena. By "newsworthy" we mean news of the "oldest" or "first" but also multidisciplinary pieces that catch the attention of numerous readers, scientist or not, archaeologist or not, with interests in diverse fields of inquiry. These might include radiometric age determinations of, say, the earliest inhabitants of a geographic place, a synthesis of the prehistory of an area, or some aspect of ancient metallurgy. Testing this hypothesis requires classification of published papers by subject matter. If this hypothesis is supported, it could reflect the influence of editorial choice on what has been published rather than whether archaeology is perceived by archaeologists to be scientific or not, remembering that editors can choose only from what has been submitted.

To test the rate hypothesis for Science, we tallied the total number of articles and reports that directly or indirectly concerned archaeology. Letters, news items by reporters and science writers, book reviews, and technical comments written as responses to reports or articles on archaeological topics were not counted. Items that indirectly concern archaeology are those such as Susman's (1994) anatomical analyses of ancient hominid hand bones, indicating that the precision grip required of habitual tool makers and users was present two million years ago. Such information is critical to our understanding of the archaeological record and holds test implications for it. Another example of an indirectly related article is Haynes's (1982) use of archaeological data to address geochronological issues of archaeological import.

Titles in Science that concern only the biological evolution of hominids were not counted. Similar rules of inclusion and exclusion attended our tallying of titles published in Scientific American. The major difference is that we tallied Scientific American articles authored by science writers. Had we instead used the criterion that a professional archaeologist be an author, the list of titles recorded for either journal would not have varied in any significant way, except that there would have been fewer titles tallied for Scientific American during the last few years. Scientific American articles on ancient feats of engineering that used only historical documents or principles of mechanics to analyze phenomena such as Roman waterworks and seagoing vessels were not tallied. Only titles making direct reference to archaeological data were counted. To interpret annual trends in both journals, we fit polynomial regression lines to point scatters 
Table 1. Descriptive Data on Annual Publication Rates of Archaeological Research in Scientific American and Science.

\begin{tabular}{|c|c|c|}
\hline$\underline{\text { Statistic (per year) }}$ & Scientific American & Science \\
\hline \multicolumn{3}{|l|}{$1940-2003$} \\
\hline Average $( \pm$ SD) number all articles & $95.39 \pm 8.62$ & $763.2 \pm 246.2$ \\
\hline Range of all articles & $66-114$ & $312-1230$ \\
\hline Average number archaeology & $4.09 \pm 2.34$ & $7.55 \pm 5.85$ \\
\hline Range of archaenlogy articles & $0-10$ & $0-23$ \\
\hline Average $( \pm S D)$ percentage archaeological & $4.21 \pm 2.41$ & $0.90 \pm 0.56$ \\
\hline Range of percentage archaeological & $0-10.2$ & $0.00-2.21$ \\
\hline 95 percent $\mathrm{CI}$ on percentage archaeological & $3.61-4.81$ & $0.76-1.04$ \\
\hline \multicolumn{3}{|l|}{$1951-2003$} \\
\hline Average $( \pm S D)$ number all articles & $97.94 \pm 5.89$ & $835.7 \pm 202.0$ \\
\hline Range of all articles & $77-114$ & $439-1230$ \\
\hline Average number archaeology & $4.62 \pm 2.02$ & $8.75 \pm 5.71$ \\
\hline Range of archaeology articles & $0-10$ & $0-23$ \\
\hline Average $( \pm \mathrm{SD})$ percentage archaeological & $4.72 \pm 2.07$ & $1.00 \pm 0.55$ \\
\hline Range of percentage archaeological & $0-10.2$ & $0-2.21$ \\
\hline 95 percent CI on percentage archaeological & $4.14-5.29$ & $0.85-1.15$ \\
\hline \multicolumn{3}{|l|}{$1965-2003$} \\
\hline Average $( \pm \mathrm{SD})$ number all articles & $98.08 \pm 6.82$ & $913.8 \pm 127.6$ \\
\hline Range of all articles & $77-114$ & $742-1230$ \\
\hline Average number archaeology & $4.46 \pm 2.16$ & $9.82 \pm 5.71$ \\
\hline Range of archaeology articles & $0-10$ & $1-23$ \\
\hline Average $( \pm \mathrm{SD})$ percentage archaeological & $4.54 \pm 2.20$ & $1.05 \pm 0.57$ \\
\hline Range of percentage archaeological & $0-10.2$ & $0.13-2.21$ \\
\hline 95 percent $\mathrm{CI}$ on percentage archaeological & $3.82-5.25$ & $0.87-1.24$ \\
\hline
\end{tabular}

representing the percentage of all articles published per year that were archaeological. Choice of a second-, third-, or fourth-order polynomial was based on the magnitude of the coefficient of determination and our combined subjective impressions regarding which line best described the temporal trend evident in the point scatter. We also use threeyear running averages of annual publication rates to smooth otherwise noisy data.

\section{Results}

The archaeology articles in Scientific American are fairly evenly distributed across the 64 years studied (Table 1). Of the 636 issues of the journal published between 1951 and 2003, 242 (38 percent) include an article on archaeology. Only one issue has more than one archaeology title, but that issue-issuc 3 of volume 203, published in September 1960 - has as its theme the biological and cultural evolution of humans. The average annual percentage of archaeological articles (among all articles) appearing in Scientific American between 1940 and 2003 was 4.2 percent (4/95), and the range was zero to 10.2 percent (Figure 1a). During the 64-year period, the annual rate of publication fluctuated markedly; a fourth-order best-fit regression line describes this fluctuation, but the low value of the coefficient of determination $\left(r^{2}=.25\right)$ suggests that the long-term trend is perhaps more apparent than real. Deletion of the extreme annual low in 1973 ( 0.99 percent) and the extreme high in 1980 (10.2 percent) from the Scientific American data does not change the coefficient of determination appreciably (from $r^{2}=.25$ to .28 ).

No archaeological articles were published in Scientific American from 1943 to 1947 (Figure 1a); only 3 articles were published in 1942 (3.7 percent of all articles published that year) and one each in 1948,1949 , and $1950(<1.1$ percent per year for all 3 years). The regression line for 1940-2003 indicates that World War II influenced the archaeology publication rate. Omitting the data from 1940 through 1950-we believe publication decisions were influenced by the myriad technological discoveries stemming from World War II-does not change the coefficient of determination or the overall shape of the regression line. Thus, even omit- 
ting the 1940-1950 data, our hypothesis that there would be an increased publication rate of archaeology in Scientific American beginning about 1965 is falsified. The rate increases after 1950 , surpasses the 1940-2003 mean in 1958, peaks in the early 1970s, and then decreases until about 2000. We consider why this is so in the discussion section.

The shape of the best-fit regression line for the three-year running average rate of publication in Scientific American is similar to that for the annual rate (compare Figure 1a with Figure 2a). Given the smoothing effect of averages, it is not surprising that the coefficient of determination is greater for the former $\left(r^{2}=.42\right)$ than for the latter $\left(r^{2}=.25\right)$. This suggests that the trend hinted at by the annual rates is real but obscured by a random factor such as the rate of submission or perhaps the timing of when papers were accepted for publication. The three-year running average-rate values indicate a marked drop in rate in the 1970s (Figure 2a), just as do the annual-rate data (Figure 1a). The drop is well below the annual mean of 4.2 percent. We are unsure why this drop occurred, but wonder if it has a cause similar to that for the apparent decreases in the middle 1950s and the early 1960s (Figure 2a). The gradual but more or less consistent decline in rate after the late 1970 s may obscure later, similar fluctuations in rate.

The average annual publication rate of archaeological research in Science between 1940 and 2003 was 0.9 percent of all titles published, and the range was zero to 2.2 percent (Table 1). On average, 763 titles were published per year, of which about 7.5 were on archaeology. During the 64-year period, the annual rate of publication fluctuated markedly (Figure 1b). The fourth-order polynomial regression line resembles that for Scientific American, but it is not identical. For one thing, the coefficient of determination is markedly stronger $\left(r^{2}=.83\right)$, suggesting the long-term trend is real. The long-term trend is particularly evident in the graph of three-year running average rates (compare Figure $1 \mathrm{~b}$ with Figure $2 \mathrm{~b}$ ). The archaeology publication rate decreased after 1943 and was very low between 1944 and 1954, but the annual rate increased in the late 1950s. This is not just recovery from the influence of World War II; the values for 1955-1959 are the highest for that decade. The hypothesis that there would be an increase in the publication rate beginning about 1965 is falsified.
The rate began to increase after 1954, exceeded the 1940-2003 mean in 1958, peaked between 1966 and 1978, decreased after that, and began to recover only after the early 1990 s.

Comparison of the regression lines for Science and Scientific American is instructive. In both journals, the increase in publication rate begins in the middle 1950s, and in both journals that rate exceeds the mean for the entire 1940-2003 period in the same year (1958). The rate of publication in Science increases from 0.9 percent in 1958 to an approximate average peak of 1.8 percent centered in the early 1970s; the rate in Scientific American increases from 4.2 percent in 1958 to an approximate average peak of about 5.5 percent in the early 1970s. There is no indication in Science of the marked decrease in rate during the 1970s evident in Scientific American (Figure 2); given earlier rate dips in the latter, perhaps the 1970s dip should be expected. The publication rate decreases much more rapidly in Science than in Scientific American after the peak in the 1970 s. The annual rate falls below the mean in 1989 in Scientific American and in 1985 in Science. But the publication rate in Science also seems to recover much sooner (in the early 1990s) than in Scientific American (perhaps in 2000), but data for the latter are too sparse to permit a definitive conclusion.

\section{Discussion}

A combination of factors likely contributed to the increasing rate of archaeology publication in both Science and Scientific American during the late 1950s. First, the post-WWII boom in land modification was accompanied by increases in federal funding directed toward protecting archaeological resources by salvage excavation (Jennings 1985). Some of the rescarch results funded by this increase appeared in the pages of these journals; however, to sort out more than a few exemplary titles (e.g., Davis and Schultz 1952; Roberts 1948; Wedel 1967) would require intimate knowledge of which sites were sampled and which artifacts were collected under the sponsorship of salvage work. That additional funds were provided by the National Science Foundation, which began supporting archaeology in 1954 (Yellen and Greene 1985), adds to the complexity. The annual amount of money that NSF furnished for archaeological 

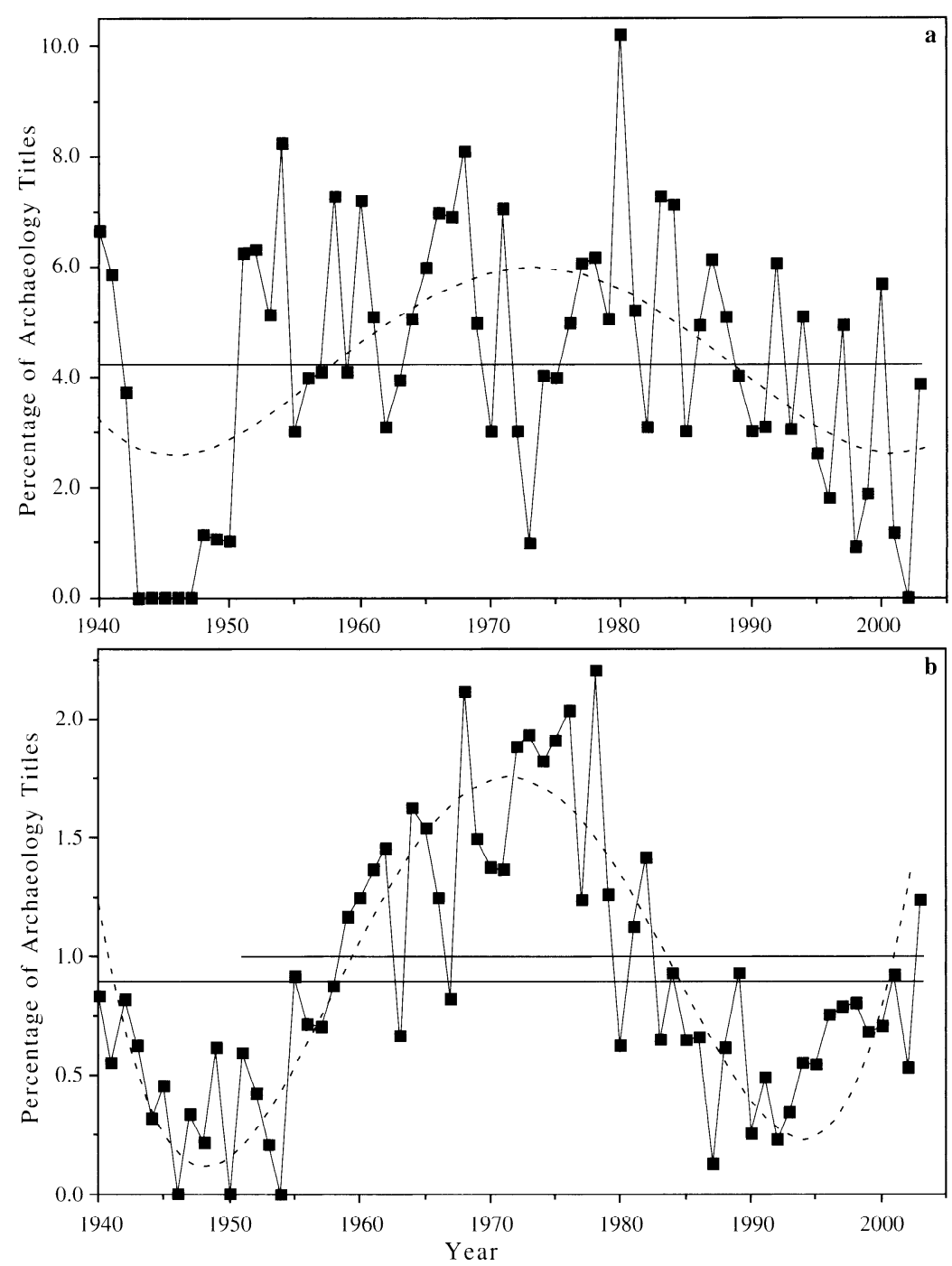

Figure 1. Percentage of all titles published per year that are archaeological. (a) Scientific American, solid line is the mean percentage for 1940 through 2003, dashed line is fourth-order polynomial best-fit regression line; (b) Science, lower horizontal solid line is the mean percentage for 1940 through $\mathbf{2 0 0 3}$, upper horizontal solid line is the mean percentage for 1951 through 2003 , dashed line is fourth-order polynomial best-fit regression line.

research between 1954 and 1983, and the annual rate of archaeology publication in Science, are correlated $(r=.514, p=.004)$. The shape of a secondorder polynomial best-fit regression line describing the relationship between NSF funds and year (Figure $\left.3 \mathrm{a} ; r^{2}=.90\right)$ is similar to the curve describing the relationship between publication rate and year (Figure 1b) for the years 1954 through 1984. In both funding amount and publication rate, there is a progressive increase after the middle 1950s that peaks in the 1970s and subsequently decreases, or at least appears to, with respect to NSF funding (Figure 3a).
A second factor that might have contributed to the increased publication rate of archaeological titles in both journals during the 1955-1975 period was the dramatic increase in the number of professional archaeologists, who obviously would have needed additional publication outlets for their findings (Schiffer 1979). The annual number of pages in the top Americanist archaeology journal, American Antiquity, defines a curve similar to those of the archaeology publication rates in Science and Scientific American (compare Figure 1 with Figure $3 b$ ). The 64-year average number of pages pub- 


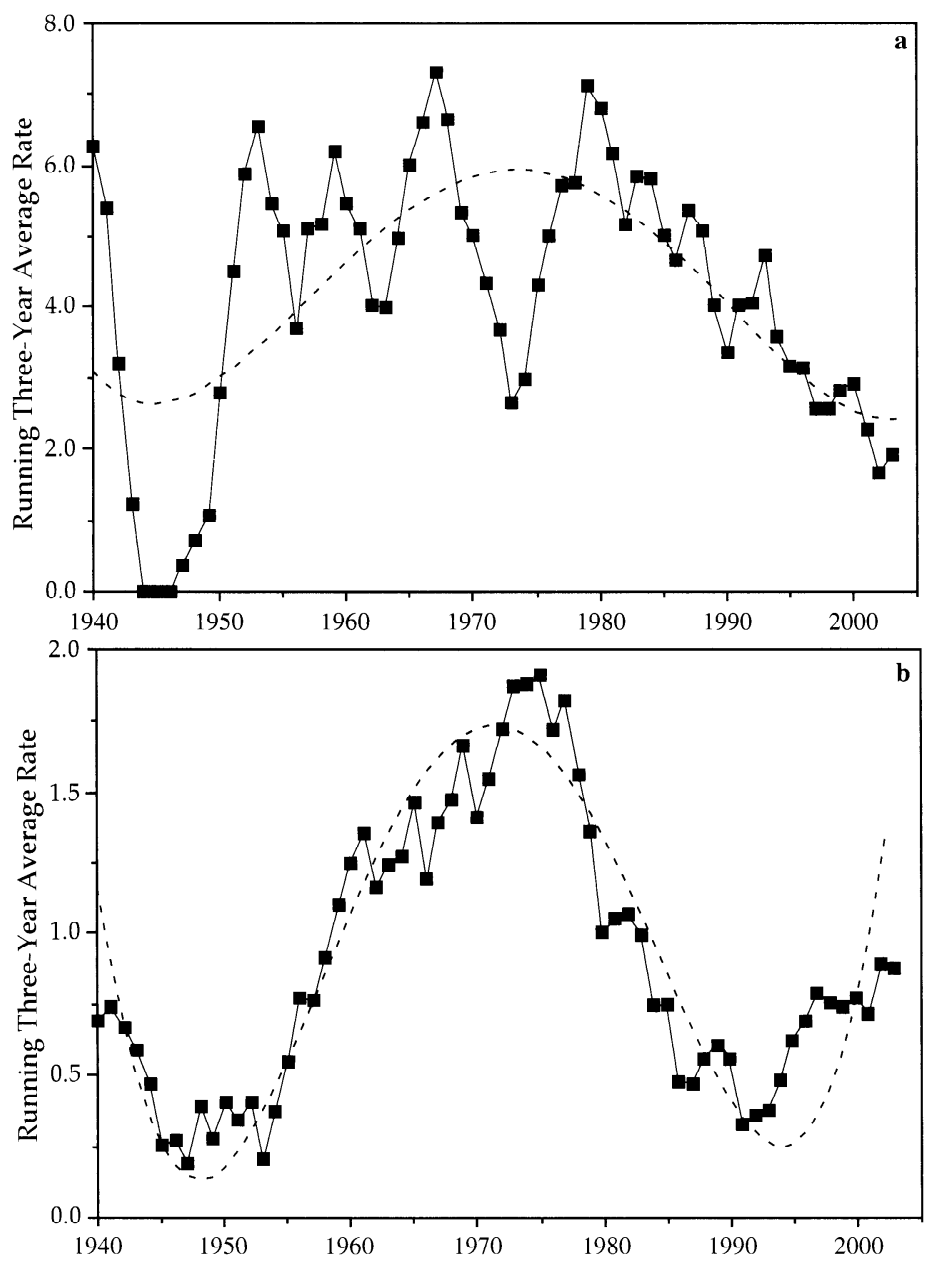

Figure 2. Three-year running average rates (percentage of all titles published) of archaeology publication. (a) Scientific American, dashed line is fourth-order polynomial best-fit regression line; (b) Science, dashed line is fourth-order polynomial best-fit regression line. Compare with Figure 1.

lished annually (=640) in American Antiquity is consistently exceeded beginning in 1976. A thirdorder polynomial $\left(r^{2}=.86\right)$ regression line indicates a slight decrease in the number of pages published in the mid 1950s, followed by an increase that peaks in 1981 and then decreases. The peak in pages of American Antiquity is a bit later than the peak in publication rate in Science and Scientific American; the correlation between the annual number of pages in American Antiquity and the rate of publication in Science between 1960 and 2003 is negative and significant $(r=-.555, p<.0001)$, suggesting more publication of archaeology generally, with American Antiquity or other, particularly new, journals publishing what Science did not. A number of specialty journals focusing on particular aspects of archaeology were founded in the 1970s and 1980s. These include Journal of Archaeological Science (first published in 1974); Journal of Field Archaeology (1974); Advances in Archaeological Method and Theory (1978, now Journal of Archaeological Method and Theory); North American Archaeologist (1980); Journal of Ethnobiology (1981); Advances in World Archaeology (1982, now Journal of World Prehistory); Journal of Anthropological Archaeology (1982); and Geoarchaeology (1986). Similarly, several new general-science publication outlets were initiated at the same time (e.g., Smithsonian in 1970, and Discover in 1980).

The third factor contributing to shifts in the rate of publication of archaeological titles in Science after 1950 appears to be editorial choice - the con- 

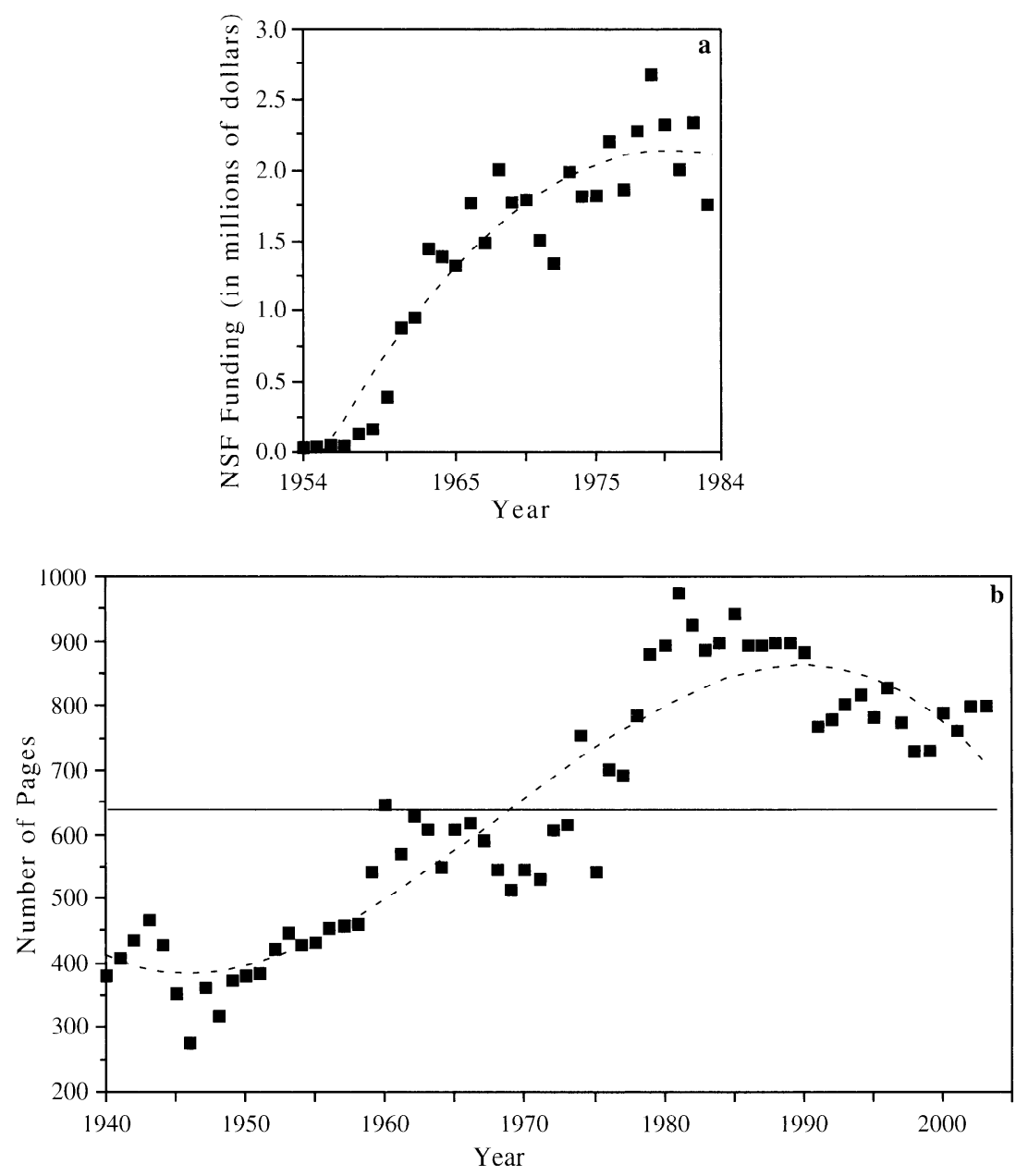

Figure 3. Amount of funding and pages published per year. (a) Rate of National Science Foundation funding (in millions of dollars) for archaeology from 1954 through 1983 [data from Yellen and Greene (1985)], dashed line is second-order polynomial best-fit regression line; (b) number of pages published in American Antiquity per year from 1940 through 2003, solid line is annual mean (640), dashed line is third-order polynomial best-fit regression line.

tent hypothesis. Tatum (1947:98) observed that "the new horizons of archaeology lie in the development of methods and practices fully applicable to all sciences." This sort of thinking is evidenced by multidisciplinary articles that we categorize generally as "archaeometry-type articles." These include reports on new chronometric techniques such as radiocarbon dating (e.g., Arnold and Libby 1949, 1951; Johnson 1967; Libby et al. 1949), thermoluminescence (e.g., Matess and Zimmerman 1966), and obsidian hydration (e.g., Johnson 1969; Meighan et al. 1968; Michels 1967); reports on ancient metallurgy (e.g., Bayard 1972; Friedman et al. 1966); and source analysis of various materials (e.g., Gordus et al. 1968; Hammond 1972;
Patton and Miller 1970). The proportion of archaeology articles that constitute archaeometry pieces is greater than one third in all but two of the 13 fiveyear periods beginning with 1940-1944 (Figure 4 ); the publication rate of archaeometry tends to be relatively stable over the 64-year period sampled. The second most abundant category of article is what we term "overviews," which can be areal (e.g., Bordes 1961; Laughlin 1963; Rouse 1964; Willey 1960) or topical (e.g., Ascher and Ascher 1965; Caldwell 1959; Heizer 1966; Howell 1959).

Overviews synthesize and summarize major data sets or issues for general scientific consumption and tend to be relatively common until about 1980, after which they decrease. Overviews are 


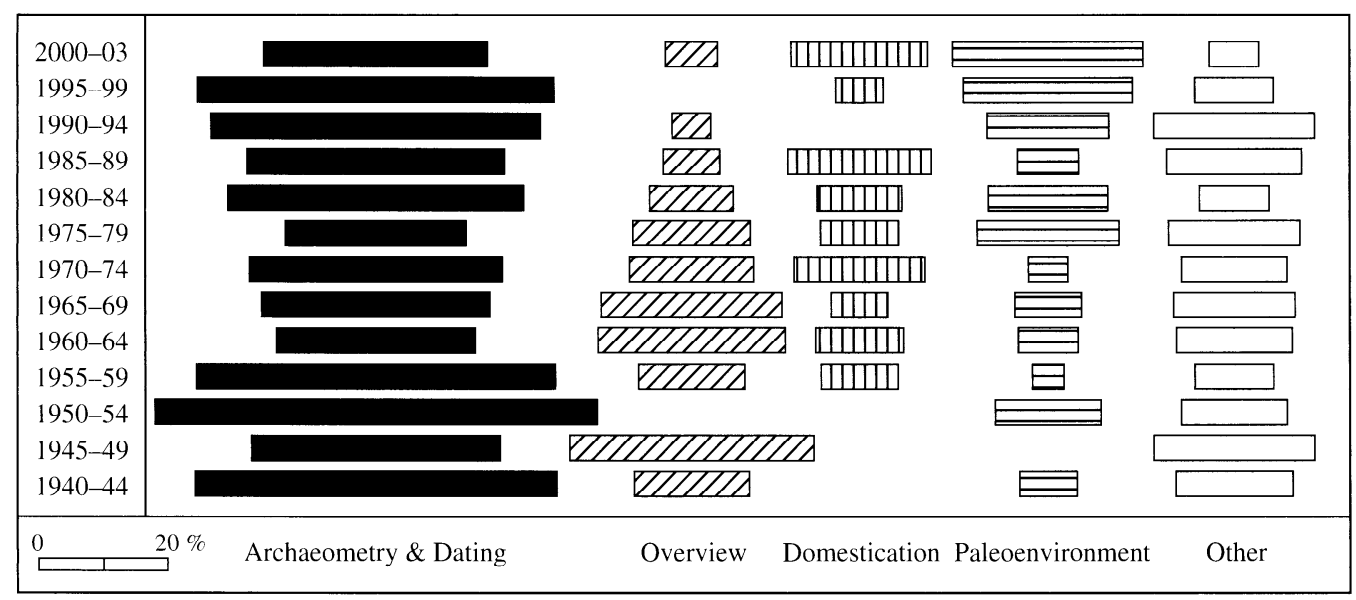

Figure 4. Percentage of each of five categories of archaeology titles published in Science in 13 multiyear periods between 1940 and 2003.

replaced by articles concerning early plant and animal domestication (e.g., Adams 1962; Evenari et al. 1961; Helbaek 1959; Isaac 1962; Reed 1959) and paleoenvironmental topics (e.g., Churcher and Smith 1972; Jelinek 1966; Klein 1975; Pearson 1977; Simenstad et al. 1978). The latter become particularly noticeable in the 1970s. We believe such shifts in content reflect changing editorial perceptions of what is newsworthy, particularly multidisciplinary studies such as domestication and paleoenvironmental studies that are likely thought by editors to be of interest to many kinds of nonarchaeological scientists (geneticists, botanists, zoologists, agriculturalists, and economists for domestication; palynologists, botanists, zoologists, climatologists, geologists, restoration ecologists, and conservation biologists for paleoenvironments). If so, our content hypothesis is not falsified.

\section{Conclusion}

Ignoring the apparent influence of World War II, the rate of archaeological publication did not increase after 1965 in Scientific American or in Science but rather after 1955. This was not just a recovery from what seem to have been influences of World War II. The claim of the processual archaeologists - that only with their assistance after about 1965 was the discipline scientific - is not reflected in the rate of publication in two major general-science journals. Of course, it need not be so reflected as there is no necessary causal relation between the claim and the publication rate. But why did the rate not change after 1965, as we expected, and instead changed earlier? It was suggested in 1970 that "despite a decade of intensive activity, relatively few research results have been reported yet by prac titioners of the new archeology" (Hammond 1970:1119), but our research contradicts this assertion (O'Brien et al. 2005). There were research results that could have been and indeed were published in Scientific American and in Science (e.g., Binford and Binford 1969; Flannery 1965; Hole 1966; Leone 1968; Longacre 1964; Wilmsen 1968).

We believe that the publication rate changed earlier because the effort to be more scientific and more anthropological attributed to the processualists (e.g., Willey and Sabloff 1993) actually began before 1960. That beginning involved in part the adoption of the cultural evolutionism of Leslie White, along with a healthy dose of Julian Steward's cultural ecology (O'Brien et al. 2005). For example, an overview of Americanist archaeology published in Science in 1959 listed three foci of what was then termed "the new American archeology"-identification of culture processes, human ecology and adaptation, and cultural evolution (Caldwell 1959). Exactly those same three foci were said to characterize Americanist archaeology of the 1960s a decade later and several years after the birth of processual archaeology; the difference supposedly was that pre-1960s archaeological research had been largely inductive whereas processual archaeology involved deduction and the explicit testing of hypotheses (Adams 1968). However, deduction and hypothesis testing were 
employed by archaeologists in the 1940s (Bennett 1946) and 1950s (Meggers 1955). In our view, what happened was less an adoption of new scientific procedures for doing research and more the creation of a cohort of archaeologists with a similar vision of the products of archaeological research; many in this cohort landed jobs in prestigious centers of research and training (particular universities) where they could influence the next generation (O'Brien et al. 2005). The products were supposed to involve "cultural processes," hence the name "processual archaeology."

The increasing publication rate evident in both journals in the 1950 s appears to have been influenced by several factors, including a greater amount of archaeological research, a higher rate of archaeological publication generally, and increased funding. Why the publication rate decreased in both journals after the late 1970s is unclear, but we suspect that editorial choice played a significant role both directly and indirectly-directly because editors accepted manuscripts that corresponded to their nonspecialist ideas of what was important in archaeology and reflected their goal to publish articles of interest to many disciplines, and indirectly because a low acceptance rate caused archaeologists to submit their manuscripts to archaeological journals, including new ones, that were more author friendly. In our view, the historical development of publishing archaeological research in journals of general science from 1940 through 2003 reflects previously unacknowledged patterns in the discipline's history.

Acknowledgments. We thank Robert D. Leonard, Todd VanPool, and several anonymous reviewers for their insightful comments and suggestions. Lorena Delgadillo produced the Spanish abstract.

\section{References Cited}

Adams, Robert McC.

1962 Agriculture and Urban Life in Early Southwestern Iran. Science 136:109-122.

1968 Archaeological Research Strategies: Past and Present. Science 160:1187-1192.

Arnold, James R., and Willard F. Libby

1949 Age Determinations by Radiocarbon Content: Checks with Samples of Known Age. Science 1 10:678-680.

1951 Radiocarbon Dates. Science 113:111-120.

Ascher, Robert, and Marcia Ascher

1965 Recognizing the Emergence of Man. Science $147: 243-250$

Bayard, Donn T.

1972 Early Thai Bronze: Analysis and New Dates. Science
176:1411-1412.

Bennett, John W.

1946 Empiricist and Experimental Trends in Eastern Archaeology. American Antiquity 11:198-200.

Binford, Lewis R.

1962 Archaeology as Anthropology. American Antiquity 28:217-225.

1968a Archeological Perspectives. In New Perspectives in Archeology, edited by Sally R. Binford and Lewis R. Binford, pp. 5-32. Aldine, Chicago.

1968b Some Comments on Historical versus Processual Archaeology. Southwestern Journal of Anthropology 24:267-275.

1972 An Archaeological Perspective. Seminar Press, New York.

Binford, Sally R., and Lewis R. Binford

1969 Stone Tools and Human Behavior. Scientific American 220(4):70-84.

Binford, Sally R., and Lewis R. Binford (editors)

1968 New Perspectives in Archeology. Aldine, Chicago.

Bordes, François

1961 Mousterian Cultures in France. Science 134:803-810.

Caldwell, Joseph R.

1959 The New American Archeology. Science 129:303-307.

Chang, K. C.

1967 Rethinking Archaeology. Random House, New York.

Churcher, C. S., and P. E. L. Smith

1972 Kom Ombo: Preliminary Report on the Fauna of Late Paleolithic Sites in Upper Egypt. Science 177:259-261.

Clarke, David L.

1968 Analytical Archaeology. Methuen, London.

Davis, E. Mott, and C. Bertrand Schultz

1952 The Archaeological and Paleontological Salvage Program at the Medicine Creek Reservoir, Frontier County, Nebraska. Science 115:288-290.

Deetz, James

1965 The Dynamics of Stylistic Change in Arikara Ceramics. Illinois Studies in Anthropology no. 4. Urbana.

Evenari, M., L. Shanan, N. Tadmore, and Y. Aharoni

1961 Ancient Agriculture in the Negev. Science 133:979-996.

Flannery, Kent V.

1965 The Ecology of Early Food Production in Mesopotamia. Science 147:1247-1255.

1967 Culture History v. Culture Process: A Debate in American Archaeology. Scientific American 217(2):119-122.

Friedman, A. M., M. Conway, M. Kastner, J. Milsted, D. Metta, P. R. Fields, and E. Olsen

1966 Copper Artifacts: Correlation with Source Types of Copper Ores. Science 152:1504-1506.

Fritz, John M., and Fred T. Plog

1970 The Nature of Archaeological Explanation. American Antiquity 35:405-412.

Gordus, Adon A., Gary A. Wright, and James B. Griffin

1968 Obsidian Sources Characterized by Neutron-Activation Analysis. Science 161:382-384.

Hammond, Allen L.

1970 The New Archeology: Toward a Social Science. Science 172:1119-1120.

Hammond, Norman

1972 Obsidian Trade Routes in the Mayan Area. Science 178:1092-1093.

Haynes, C. Vance, Jr.

1982 Great Sand Sea and Selima Sand Sheet, Eastern Sahara: Geochronology of Desertification. Science 217:629-633. 
Heizer, Robert F.

1966 Ancient Heavy Transport, Methods and Achievements. Science 153:821-830.

Helbaek, Hans

1959 Domestication of Food Plants in the Old World. Science 130:365-372.

Hole, Frank A.

1966 Investigating the Origins of Mesopotamian Civilization. Science 153:605-611.

1974 Editorial Comment. American Antiquity 39:405.

Howell, F. Clark

1959 The Villafranchian and Human Origins. Science 130:831-844.

Isaac, Erich

1962 On the Domestication of Cattle. Science 137:195-204.

Jelinek, Arthur J.

1966 A Correlation of Archaeological and Palynological Data. Science 152:1507-1509.

Jennings, Jesse D.

1985 River Basin Surveys: Origins, Operations, and Results, 1945-1969. American Antiquity 50:281-296.

Johnson, Frederick

1967 Radiocarbon Dating and Archaeology in North America. Science 155:165-169.

Johnson, LeRoy, Jr.

1969 Obsidian Hydration Rate for the Klamath Basin of California and Oregon. Science 165:1354-1356.

Kidder, A. V.

1932 The Artifacts of Pecos. Papers of the Southwestern Expedition, Phillips Academy no. 6. Yale University Press, New Haven, Connecticut.

Klein, Richard G. 1975 Middle Stone Age Man-Animal Relationships in Southern Africa: Evidence from Die Kelders and Klasies River Mouth. Science 190:265-267.

Kushner, Gilbert

1970 A Consideration of Some Processual Designs for Archaeology as Anthropology. American Antiquity 35:125-132.

Laughlin, William S.

1963 Eskimos and Aleuts: Their Origins and Evolution. Science 142:633-645.

Leone, Mark P.

1968 Neolithic Economic Autonomy and Social Distance. Science 162:1150-1151.

Libby, Willard F., Ernest C. Anderson, and James R. Arnold 1949 Age Determination of Radiocarbon Content: WorldWide Assay of Natural Radiocarbon. Science 109:227-228

Longacre, William A.

1964 Archaeology as Anthropology: A Case Study. Science 144:1454-1455.

Matess, Richard B., and D. W. Zimmerman

1966 Pottery Dating from Thermoluminescence. Science 152:347-348

Meggers, Betty J.

1955 The Coming of Age of American Archaeology. In New Interpretations of Aboriginal American Culture History, edited by Betty J. Meggers and Clifford Evans, pp. 116-129. Anthropological Society of Washington, Washington, D.C

Meighan, Clement W., Leonard J. Foote, and Paul V. Aillo 1968 Obsidian Dating in West Mexican Archeology. Science 160:1069-1075.

Meyerhoff, Howard A.

1952 The Content of Science. Science 115(2997):3a.

Michels, Joseph W.
1967 Archeology and Dating by Hydration of Obsidian. Science 158:211-214.

Nemecek, Sasha

2000 Who Were the First Americans? Scientific American 283(3):80-87.

O'Brien, Michael J., R. Lee Lyman, and Michael Brian Schiffer 2005 Archaeology as a Process: Processualism and Its Progeny. University of Utah Press, Salt Lake City.

Patton, William W., Jr., and Thomas P. Miller

1970 A Possible Bcdrock Source for Obsidian Found in Archeological Sites in Northwestern Alaska. Science 169:760-761.

Pearson, Richard

1977 Paleoenvironment and Human Settlement in Japan and Korea. Science 197:1239-1246.

Plog, Fred

1982 Is a Little Philosophy (Science?) a Dangerous Thing? In Theory and Explanation in Archaeology, edited by Colin Renfrew, Michael J. Rowlands, and Barbara A. Segraves, pp. 25-33. Academic Press, New York.

Reed, Charles A

1959 Animal Domestication in the Prehistoric Near East. Science 130:1629-1639.

Roberts, Frank H. H.

1948 A Crisis in U.S. Archaeology. Scientific American 179(6):12-17.

Rouse, Irving B.

1964 Prehistory of the West Indies. Science 144:499-513.

Schiffer, Michael Brian

1979 Some Impacts of Cultural Resource Management on American Archaeology. In Archaeological Resource Management in Australia and Oceania, edited by J. R. McKinlay and K. L. Jones, pp. 1-11. New Zealand Historic Places Trust, Wellington.

Simenstad, Charles A., James A. Estes, and Karl W. Kenyon 1978 Aleuts, Sea Otters, and Alternate Stable-State Communities. Science 200:403-411.

Stcrud, Eugene L.

1978 Changing Aims of Americanist Archaeology: A Citations Analysis of American Antiquity-1946-1975. American Antiquity 43:294-302.

Susman, Randall L.

1994 Fossil Evidence for Early Hominid Tool Use. Science 265:1570-1573.

Tatum, R. M.

1947 New Horizons in Archacology. Science 106:97-98.

Watson, Patty Jo, Steven A. LeBlanc, and Charles L. Redman 1971 Explanation in Archeology: An Explicitly Scientific Approach. Columbia University Press, New York.

Wedel, Waldo R

1967 Salvage Archaeology in the Missouri River Basin. Science 196:589-597.

Willey, Gordon R.

1960 New World Prehistory. Science 131:73-83.

Willey, Gordon R., and Jeremy A. Sabloff

1993 A History of American Archaeology, third edition. Freeman, New York.

Wilmsen, Edwin N.

1968 Lithic Analysis in Paleoanthropology. Science 161:982-987.

Yellen, John E., and Mary W. Greene

1985 Archaeology and the National Science Foundation. American Antiquity 50:332-341.

Received June 8, 2004; Revised Sept. 26, 2004; Accepted

Sept 28, 2004. 